\title{
UCHODŹSTWO, MIGRACJE, UCIECZKA, PRZESIEDLENIA, REPATRIACJE JAKO „UNIWERSALNE” DOŚWIADCZENIE DZIEJOWE - UWAGI WPROWADZAJĄCE
}

I poznaja, że Ja jestem Pan, gdy ich rozprosze na wszystkie wiatry i miecza na nich dobędę. Ale niektórych z nich, którzy ujda miecza, głodu i zarazy, pozostawię, aby pomiędzy narodami, do których przybęda, opowiadali o wszystkich swoich obrzydliwościach.

Stary Testament, Księga Ezechiela 12, 15-16

Wojny zawsze niosły ze sobą - i niestety wciąż niosą - zagrożenia dla ludności cywilnej, o czym można niemal codziennie dowiedzieć się z mediów. Migracje wymuszone działaniami zbrojnymi towarzyszyły wojnom od zarania dziejów, czego dowodem jest chociażby powyższy cytat z Biblii, a doświadczenie uchodźców wojennych pozostaje doświadczeniem ponadczasowym. Jednak intuicja nakazuje przypuszczać, że w różnych epokach i kręgach kulturowych ich uwarunkowania były odmienne: zarówno pod względem religijnym, jak i społecznym, kulturowym czy prawnym. Zróżnicowane pozostawały również skala migracji oraz relacje między ich uczestnikami a wojskiem. Władze państw, z których uchodźcy pochodzili lub w których szukali schronienia, społeczeństwa ich przyjmujące, a także międzynarodowe gremia stosowały różne strategie radzenia sobie z tym wyzwaniem.

Pomocą uchodźcom od zarania swego istnienia zajmuje się Organizacja Narodów Zjednoczonych. Od 1950 roku w ONZ istnieje urząd Wysokiego Komisarza Narodów Zjednoczonych do spraw Uchodźców. Aby zwrócić uwagę światowej opinii publicznej na ich los, w 2000 roku Zgromadzenie Ogólne ONZ ustanowiło Światowy Dzień Uchodźcy obchodzony 20 czerwca. Migracje okresu wojny niezmiennie stanowią doświadczenie o charakterze masowym: w 2017 roku ONZ szacowała liczbę uchodźców na świecie na ponad $25 \mathrm{mln}$, zaś łączną liczbę osób określanych mianem forcibly displaced persons na $68 \mathrm{mln}$ w skali globu. Trudno dziś jednoznacznie i precyzyjnie odróżnić uchodźców ekonomicznych, politycznych i religijnych od tych zmuszonych do ucieczki przez działania wojenne. Od sierpnia 2017 roku lud Rohingjów był wypędzany ze swych domostw w Mjanmie. Fala migracji wywołanej przez mjanmańskie bojówki wyniosła 900 tys. osób. W Darfurze w zachodnim Sudanie od 2003 roku 2 mln osób zostało zmuszonych do opuszczenia swych siedzib. W Syrii wojna domowa, która trwa od 2011 roku, dotknęła 22 mln ludzi. Uchodźcami wewnętrznymi stało się $6 \mathrm{mln}$ osób, a $5 \mathrm{mln}$ (stan na 2016 rok) musiało uciekać za granicę. Ponad $13 \mathrm{mln}$ osób potrzebuje pomocy. We wrześniu 2017 roku Etiopia gościła na swym terytorium 880 tys. uchodźców z takich krajów sąsiednich 
jak Sudan, Sudan Południowy, Somalia i Erytrea. Gdy oddajemy ten numer „Prac Historycznych" do druku, do opuszczenia ogarniętego wojną domową Afganistanu szykują się kolejne miliony zdesperowanych obywateli tego kraju. To jedynie wybrane przykłady globalnego problemu przymusowych migracji z ostatnich lat - nic więc dziwnego, że w obliczu tak zauważalnych zjawisk, obserwując bieżące ruchy uchodźców trafiających do Europy, również i środowiska naukowe zwróciły uwagę na problem kryzysów migracyjnych.

Dlatego też historiografia wzbogaciła się o nowe opracowania przekrojowe ${ }^{1}$. W kontekście tej problematyki najszerzej omówiony został wiek XX, określany stuleciem wypędzenia i uchodźstwa. Uzasadnić to można skalą konfliktów zbrojnych o charakterze światowym w tym okresie. I i II wojna światowa wraz z ich konsekwencjami - reorganizacją przestrzeni postimperialnych, postkolonialnych, zarysowaniem nowych granic państw w Europie i nie tylko - zarówno przed wybuchem konfliktów, w ich trakcie, jak i po ich zakończeniu wpływały na ruchy migracyjne ludności cywilnej na różnym tle i w różnych okolicznościach. Niniejszy zeszyt „Prac Historycznych" pokazuje, że doświadczenie to faktycznie było zintensyfikowane w ostatnim stuleciu, jednak we wcześniejszych okresach również występowało na sporą skalę. Stąd też pojęcia ucieczki, uchodźstwa, ewakuacji, przesiedleń czy repatriacji pozostają uniwersalnym doświadczeniem w różnych realiach czasoprzestrzennych, politycznych, społecznych czy gospodarczych.

Zeszyt składa się z 15 studiów analizujących wybrane zagadnienia $\mathrm{z}$ historii migracji w miejscach zróżnicowanych pod względem geograficznym, a co za tym idzie, także i kulturowym. Okres starożytności ujęty został w tekście Tomasza Ładonia, który analizuje problemy uchodźstwa politycznego pod wpływem wewnętrznych wydarzeń w czasie Republiki Rzymskiej, oraz w artykule Michała Norberta Faszczy, omawiającym uchodźstwo ludności cywilnej w wyniku rzymskiego podboju Galii. W dalszej kolejności ujęto okres przełomu epok i wczesnego średniowiecza: Teresa Wolińska pisze o paulicjanach w Bizancjum, a Sławomir Bralewski analizuje problem migracji w kontekście kryzysu gockiego. Studia z epoki nowożytnej stanowią dwa teksty. Pierwszy to opracowanie Wojciecha Krawczuka odnoszące się do badań nad uchodźstwem ze Skandynawii w Rzeczypospolitej pod rządami Zygmunta III Wazy. Drugi tekst poświęcony nowożytności, autorstwa Artura Goszczyńskiego, omawia losy uciekinierów - uchodźców cywilnych - w czasach powstania Chmielnickiego na kresach Rzeczypospolitej. Uchodźstwu epoki nowoczesnej poświęcono aż pięć artykułów. Dwa z nich dotyczą obszaru imperium osmańskiego: studium Krzysztofa Popka traktujące o uchodźstwie w kontekście serbskim oraz tekst Dariusza Faszczy podejmujący wątek migracji wojennych w czasie II wojny bałkańskiej. Okres I wojny światowej analizują trzej badacze. Kamil Ruszała w swoim studium opisuje los uchodźców wojennych z Galicji w Austro-Węgrzech, starając się dokonać

${ }^{1}$ Zob. np. K.J. B ade, Migration in European History, Malden 2003; M.H. Fischer, Migration: A World History, Oxford 2013; J.M. Piskorski, Wygnańcy. Przesiedlenia i uchodźcy w dwudziestowiecznej Europie, Warszawa 2010; P. Ther, The Outsiders: Refugees in Europe since 1492, Princeton 2019; P. Gatre11, The Unsettling of Europe: How Migration Reshaped a Continent, New York 2019; A. Kossert, Flucht - Eine Menschheitsgeschichte, München 2020. 
oceny systemu ich relokacji zorganizowanego pośpiesznie przez rząd austriacki. Piotr Szlanta podjął wątek odzwierciedlenia uchodźstwa wojennego w sztuce wizualnej, analizując studium przypadku zachodnich części prowincjii dostarczając w ten sposób dowodów na to, że recepcja losu uchodźców obecna jest w kulturze od stuleci. Marcin Rzepka przedstawił migracje ludności asyryjskiej w czasie I wojny światowej, ukazując, w jaki sposób masowe migracje stymulują przemiany społeczne i są bodźcem do zmian modernizacyjnych. Doświadczenie uchodźstwa w epoce najnowszej odzwierciedlają teksty czterech autorów, z czego dwa dotyczą lat II wojny światowej, dwa zaś okresu powojennego. Studium Jacka Pietrzaka charakteryzuje elity II Rzeczypospolitej na uchodźstwie w Iranie podczas II wojny światowej, zaś Beata Kozaczyńska zarysowała postawy mieszkańców wschodnich powiatów dystryktu warszawskiego, którzy ratowali polskie dzieci w latach 1942-1943. Okresu powojennego dotyczą dwa teksty: Aleksandry Syllburskiej, opisującej repatriację (czy też reemigrację) Polaków z Węgier po 1945 roku, oraz Tomasza Korbana, który przeanalizował sposób prezentowania tak zwanych dipisów na łamach emigracyjnej prasy wydawanej w Londynie.

Autorzy i redaktorzy przedstawili w swych tekstach wiele interesujących spostrzeżeń odnoszących się do problemów migracyjnych czasu wojen, zmuszając do refleksji nad ich paralelami ze współczesnymi zjawiskami. Poza odniesieniami do szerzej znanych wątków proponowany zbiór tekstów zawiera również rewizje niektórych poglądów z zakresu uchodźstwa wojennego, a także analizy wielu nieomawianych w historiografii problemów.

Kamil Ruszała

Piotr Szlanta 
